\title{
ADRENAL CORTICAL REGULATION OF THE DISTRIBUTION OF WATER AND ELECTROLYTES IN THE HUMAN BODY ${ }^{1}$
}

\author{
By A. G. HILLS, T. M. CHALMERS, 2 G. D. WEBSTER, JR., ${ }^{3}$ AND OTTO ROSENTHAL \\ WITH THE TECHNICAL ASSISTANCE OF HANA CONOVER AND ELIZABETH SONGSTER
}

(From the Edward B. Robinette Foundation, Medical Clinic, and the Chemical Section, Department of Medicine, Hospital of the University of Pennsylvania, and the Harrison Department of Surgical Research, School of Medicine, University of

Pennsylvania, Philadelphia, Pa.)

(Submitted for publication November 10, 1952; accepted August 11, 1953)

Marked disturbances of fluid and electrolyte distribution have been reported to accompany experimental adrenal insufficiency. Swingle and his associates (1-4), studying the development of acute adrenal insufficiency in dogs, noted that the external loss of sodium and water appeared to be quantitatively inadequate to account for the observed dehydration and hemoconcentration. They concluded that adrenal cortical hormone renders intracellular water and electrolytes available for replenishment of the depleted extracellular fluid in adrenal insufficiency $(3,4)$. More recently, other studies in dogs have shown that a large decrease of the inulin space follows adrenalectomy (5), and that the calculated loss of sodium and chloride from the mannitol and thiocyanate spaces during acute adrenal insufficiency consistently exceeds net external loss (6). Internal transfers of water and electrolytes are therefore indicated.

Analyses of the soft tissues of animals of various species dying in acute adrenal insufficiency have, however, been consistently reported to indicate either no change or an actual decrease of cellular sodium in all soft tissues studied, although cell water and potassium are said to be increased (7-11). The intracellular migration of water has generally been assumed to be a passive osmotic process resulting from extracellular hyponatremia $(8,9,10)$. Bone has been suggested as a possible site for the sodium transferred from the mannitol space, but

\footnotetext{
1 This investigation was supported in part by research grants from the National Heart Institute, U. S. Public Health Service, the Squibb Institute for Medical Research, Sandoz Pharmaceuticals, Eli Lilly and Company, Ciba Pharmaceutical Products, Inc., and the Francis and Marian Boyer Fund.

2 Nuffield Foundation Traveling Fellow. Present address: Medical Unit, Royal Infirmary, Cardiff, Wales.

8 Trainee of the National Heart Institute.
}

relevant evidence is lacking $(6,12)$. The subject has recently been reviewed by Overman (13).

In this communication are reported studies of the effects of acute adrenal insufficiency and of adrenal steroids upon fluid and electrolyte distribution in man.

\section{MATERIALS AND METHODS}

\section{Clinical material and design of experiments}

Eleven patients previously subjected to subtotal adrenalectomy because of severe hypertensive disease and one patient with hypertensive disease not surgically treated served as experimental subjects. The experiments were of three kinds : 1) Observations of effects of acute adrenal insufficiency experimentally provoked by a standard regimen; 2) control observations in two of the subtotally adrenalectomized patients who did not develop adrenal insufficiency on the standard regimen and in one unoperated hypertensive individual subjected to drastic reduction of sodium intake; and 3 ) studies of the effects of various steroids upon fluid distribution in certain of the adrenal-deficient patients.

Nine of the patients who had previously undergone subtotal adrenalectomy were subjected to a standard regimen designed to induce a state of acute adrenal cortical insufficiency. The procedure was as follows: patients were admitted to the Metabolic Unit for a six-day balance study, which was subdivided into a three-day control period followed by a three-day experimental period. The diet and fluid intake were kept constant throughout the study, save for a substantial supplement of sodium and chloride given to five patients during the control period. Each patient continued during the control period to receive his usual steroid replacement therapy (Table I).

During the subsequent three-day experimental period all steroid therapy was withdrawn, and the constant daily diet received by all patients was of standard composition in all respects, including its content of sodium (103 to $118 \mathrm{mEq}$.) and potassium (75 to $80 \mathrm{mEq}$.). Daily measurements were made of serum sodium, chloride, potassium, protein, and urea; of total urinary sodium, chloride, potassium, creatinine, and nitrogen; and of total sodium, chloride, potassium, and nitrogen in the stool and vomitus, if any.

The inulin space was measured on the morning of the last control day and again in all patients on the morning of 
TABLE I

Patients studied-description and experimental conditions

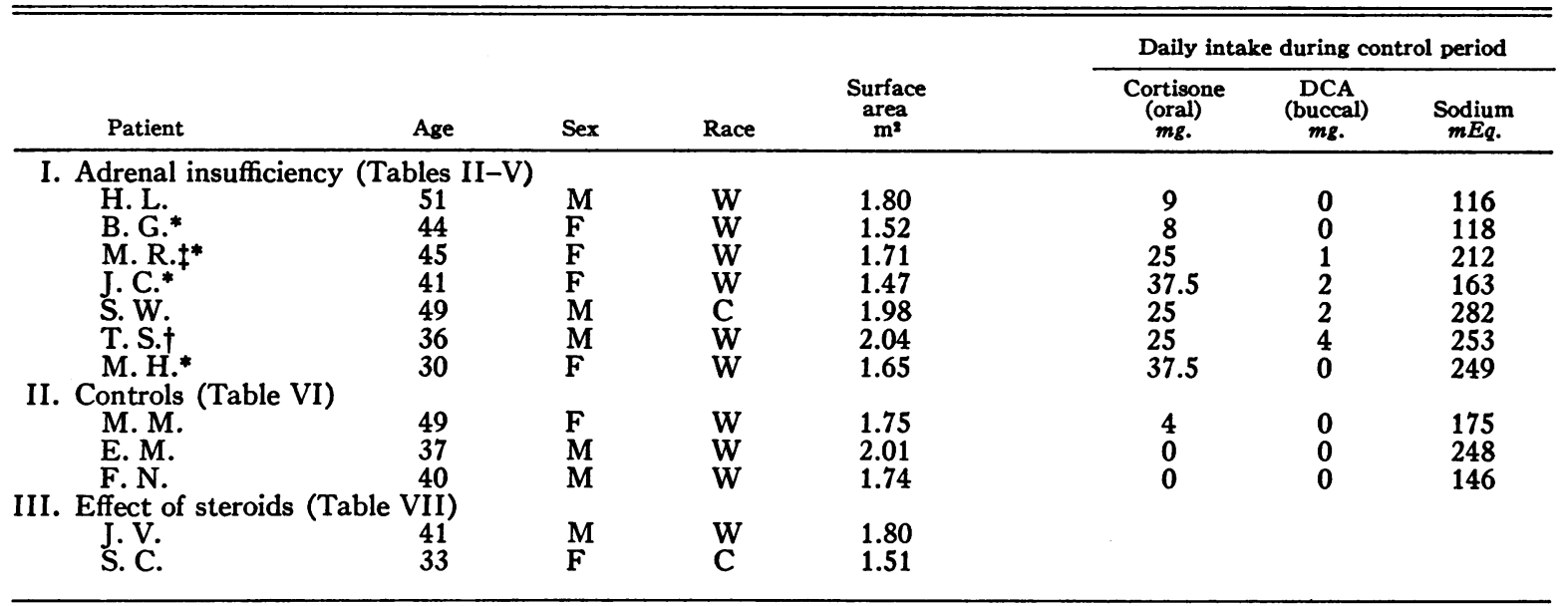

* Effect of steroid studied following precipitation of adrenal insufficiency. (Table VII). † Steroid effect studied in separate experiment.

$\ddagger$ DCA continued throughout experimental period.

the third day after hormone withdrawal. In three of these patients (B. G., M. R., and J. C.) the immediate effect upon the inulin space of intravenous cortisone, administered over a period of an hour or less, was studied at the time of the second inulin space measurement. In S. C., a subtotally adrenalectomized patient maintained in good health by sodium chloride without steroid therapy, a measurement of the effect of intravenous cortisone upon the inulin space was made without first attempting to induce adrenal cortical insufficiency by salt withdrawal (Table VII).

The balance studies were carried out on an air-conditioned metabolic ward, the room temperature being kept between 70 and $75^{\circ} \mathrm{F}$. The diets were specially prepared in the Metabolic Unit from meats, canned fruits, and vegetables bought in uniform lots. The mineral and nitrogen composition of the diets was calculated from mean values of multiple analyses performed on representative aliquots.

Pertinent clinical information concerning the patients studied is summarized in Table I. Seven adrenal-deficient patients placed on the standard regimen developed symptomatic and chemical evidence of mild to severe acute adrenal insufficiency by the end of the third day of hormone withdrawal (Tables II to $\mathrm{V}$ inclusive). All showed little or no response, as judged by the electrolyte balances and urinary steroid excretion, to an eight-hour intravenous infusion of 10 units of corticotrophin.4

Two patients who had had a prior subtotal adrenalectomy (M. M. and E. M.) failed to develop symptomatic or chemical evidence of adrenal insufficiency on the standard regimen, and an eight-hour intravenous infusion of 10 units of corticotrophin was followed by clear-cut evi-

4 We are grateful to Dr. E. G. Vonder Heide, of ParkeDavis and Company, for a generous supply of this material. dence of available adrenocortical reserve in terms of electrolyte balances and urinary steroid excretion. These data are presented in detail elsewhere (14). These patients, together with $F$. N., a hypertensive individual subjected to three days of drastic dietary salt restriction, provide control observations for comparison with the series of patients in whom acute adrenal insufficiency developed (Tables I and VI).

The effect of certain adrenal steroids on fluid distribution was examined in seven adrenal-deficient subjects. In addition to the four experiments in which immediate effects of cortisone were studied, the effect of hydrocortisone in adrenal insufficiency was observed in M. H., the effect of substitution of cortisone for desoxycorticosterone in T. S., and the effect of adding desoxycorticosterone to a basal ration of cortisone in J. V. The experimental conditions and results of these studies are presented in Table VII.

\section{Measurements and calculations}

Measurements were made of the volume of inulin distribution, after Schwartz, Schachter, and Freinkel (15), by giving an intravenous priming injection of $2.5 \mathrm{Gm}$. of inulin followed by an intravenous infusion of the major portion of a solution of $7.5 \mathrm{Gm}$. inulin in $575 \mathrm{ml} .5$ per cent dextrose at a rate of $1 \mathrm{ml}$. per minute. After four and one-half hours, the bladder was washed out and catheter urine collections begun for three 20 to 30 minute periods. Blood samples were collected in the middle of the periods for inulin analysis, and the inulin clearance was measured. Urine was collected for approximately 18 hours after the termination of the inulin infusion. From the total inulin recovered in this sample and the constant plasma inulin, an "uncorrected" inulin space can be calculated. 
In order to minimize the dead-space error, a "corrected" inulin space has been calculated, based upon an arbitrarily assumed value of $30 \mathrm{ml}$. for the volume of the urinary passages from glomerulus to bladder:

where

$$
\mathrm{E}_{\mathrm{INer}}=\frac{\mathrm{In}_{\mathrm{u}}-.03 \times(\mathrm{In})_{\mathrm{u}}}{(\operatorname{In})_{\mathrm{sw}}}
$$

$\mathrm{E}_{\mathrm{INor}}=$ corrected inulin space in liters

$\mathrm{In}_{\mathbf{u}}=$ total inulin in milligrams recovered in the urine after stopping the infusion

$(\mathrm{In})_{\mathrm{u}}=$ concentration of inulin in the urine collected at the time infusion stopped in milligrams per liter

$(\mathrm{In})_{\mathrm{ow}}=$ concentration of inulin in serum water during the clearance periods in milligrams per liter

In the experiments in which the immediate effect of cortisone was studied, three extra clearance periods were performed while intravenous cortisone was being infused. The inulin space, as affected by cortisone, was calculated from the total inulin recovered and the plasma inulin during the cortisone infusion. The inulin present in the body just prior to cortisone administration was obtained from the total inulin recovered by deducting the inulin infused, and adding the inulin recovered in the urine, during the cortisone infusion. The inulin space prior to the ad- ministration of cortisone was then calculated from the plasma values prior to the cortisone infusion. The correction for the pre-cortisone inulin space was based upon the urinary inulin concentration in the last pre-cortisone clearance period.

All values for inulin concentration in body water, as well as for electrolyte concentrations, were calculated from the serum concentrations and the formula for serum water of Eisenman, Mackenzie, and Peters (16) :

$$
\left(\mathrm{H}_{2} \mathrm{O}\right)_{8}=0.986-0.00745 \mathrm{P}
$$

where $P$ is serum protein in grams per 100 milliliters and $\left(\mathrm{H}_{2} \mathrm{O}\right)$. is serum water in kilograms per liter of serum.

Values for electrolyte in the inulin space were obtained as follows: the interstitial water concentrations were calculated as plasma water values to which, in the case of sodium and chloride, the Donnan factor correction (0.95) was applied. The extracellular water concentrations of all electrolytes were calculated as follows:

where

$$
(\mathrm{Cl})_{\mathrm{eCw}}=\frac{(\mathrm{Cl})_{\mathrm{sw}}+3(\mathrm{Cl})_{\mathrm{isw}}}{4}
$$

and

$$
\text { ecw }=\text { extracellular water }
$$$$
\mathrm{sw}=\text { serum water }
$$

isw $=$ interstitial water

\begin{tabular}{|c|c|c|c|c|c|c|c|c|c|c|c|c|}
\hline \multirow[b]{2}{*}{ Patient } & \multicolumn{5}{|c|}{ Serum concentrations* } & \multicolumn{3}{|c|}{$\begin{array}{l}\text { Concentration in extra- } \\
\text { cellular water* }\end{array}$} & \multicolumn{3}{|c|}{ Inulin space } & \multirow{2}{*}{$\begin{array}{c}\begin{array}{c}\text { Inulin } \\
\text { clearance* }\end{array} \\
\text { IS.E.M. } \\
\text { ml./min. }\end{array}$} \\
\hline & $\begin{array}{c}\text { Protein } \\
\underset{\%}{m} .\end{array}$ & $\begin{array}{c}N a \\
m E q . / \\
L .\end{array}$ & $\begin{array}{c}\mathrm{Cl} \\
m E q . / \\
L .\end{array}$ & $\underset{\substack{\mathrm{K} \\
\mathrm{m} q . / \\
L .}}{\mathrm{K}}$ & $\begin{array}{c}\text { Urea } \\
\mathrm{Nt} \\
\text { mg. } \\
\% \\
\end{array}$ & $\begin{array}{c}\mathrm{Na} \\
m \mathrm{Eq} . / \\
L .\end{array}$ & $\begin{array}{c}\mathrm{Cl} \\
\mathrm{mEq} . / \\
L .\end{array}$ & 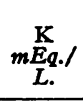 & $\begin{array}{l}\mathrm{E}_{\mathrm{IN}} * \\
\text { liters }\end{array}$ & $\begin{array}{l}\Delta \mathrm{E}_{\mathrm{IN}} \\
\text { liters }\end{array}$ & $\begin{array}{c}\Delta \mathrm{E}_{\mathrm{IN}} \\
\% \\
\end{array}$ & \\
\hline H. L. & $\begin{array}{l}7.3 \\
7.2\end{array}$ & $\begin{array}{l}134 \\
121\end{array}$ & $\begin{array}{l}97 \\
98\end{array}$ & $\begin{array}{l}5.2 \\
5.5\end{array}$ & $\begin{array}{l}43 \\
43\end{array}$ & $\begin{array}{l}138.4 \\
124.9\end{array}$ & $\begin{array}{r}108.2 \\
99.3\end{array}$ & $\begin{array}{l}5.60 \\
5.90\end{array}$ & $\begin{array}{l}8.6 \\
7.4\end{array}$ & -1.2 & -14 & $\begin{array}{l}41 \text { and } 36 \\
40 \pm 5.5\end{array}$ \\
\hline B. G. & $\begin{array}{l}7.6 \\
7.8\end{array}$ & $\begin{array}{l}135 \\
137\end{array}$ & $\begin{array}{l}99 \\
99\end{array}$ & $\begin{array}{l}4.8 \\
4.6\end{array}$ & $\begin{array}{l}22 \\
23\end{array}$ & $\begin{array}{l}139.8 \\
142.0\end{array}$ & $\begin{array}{l}110.8 \\
110.8\end{array}$ & $\begin{array}{l}5.16 \\
4.95\end{array}$ & $\begin{array}{l}9.6 \\
7.9\end{array}$ & -1.5 & -16 & $\begin{array}{r}99 \pm 24.1 \\
100 \pm \quad 7.2\end{array}$ \\
\hline M. R. & $\begin{array}{l}7.3 \\
7.5\end{array}$ & $\begin{array}{l}141 \\
139\end{array}$ & $\begin{array}{l}98 \\
98\end{array}$ & $\begin{array}{l}4.2 \\
5.2\end{array}$ & $\begin{array}{l}18 \\
21\end{array}$ & $\begin{array}{l}145.6 \\
143.4\end{array}$ & $\begin{array}{l}109.4 \\
109.5\end{array}$ & $\begin{array}{l}4.72 \\
5.81\end{array}$ & $\begin{array}{l}7.5 \\
5.5\end{array}$ & -2.0 & -27 & $\begin{array}{l}77 \pm 1.0 \\
97 \pm 8.2\end{array}$ \\
\hline J. C. & $\begin{array}{l}6.8 \\
7.1\end{array}$ & $\begin{array}{l}142 \\
138\end{array}$ & $\begin{array}{l}104 \\
104\end{array}$ & $\begin{array}{l}4.2 \\
4.2\end{array}$ & $\begin{array}{l}32 \\
41\end{array}$ & $\begin{array}{l}145.9 \\
142.4\end{array}$ & $\begin{array}{l}115.6 \\
115.9\end{array}$ & $\begin{array}{l}4.49 \\
4.50\end{array}$ & $\begin{array}{l}7.5 \\
4.8\end{array}$ & -2.7 & -36 & $\begin{array}{l}50 \pm 1.7 \\
45 \pm\end{array}$ \\
\hline S. W. & $\begin{array}{l}6.9 \\
7.1\end{array}$ & $\begin{array}{l}139 \\
138\end{array}$ & $\begin{array}{l}107 \\
103\end{array}$ & $\begin{array}{l}5.3 \\
5.7\end{array}$ & $\begin{array}{l}36 \\
47\end{array}$ & $\begin{array}{l}143.2 \\
142.4\end{array}$ & $\begin{array}{l}119.1 \\
114.8\end{array}$ & $\begin{array}{l}5.67 \\
6.11\end{array}$ & $\begin{array}{l}15.3 \ddagger \\
10.0\end{array}$ & -5.3 & -35 & $74 \pm 16.9$ \\
\hline T. S. & $\begin{array}{l}6.8 \\
6.4\end{array}$ & $\begin{array}{l}142 \\
140\end{array}$ & $\begin{array}{l}106 \\
103\end{array}$ & $\begin{array}{l}5.0 \\
5.4\end{array}$ & $\begin{array}{l}33 \\
48\end{array}$ & $\begin{array}{l}146.2 \\
144.0\end{array}$ & $\begin{array}{l}117.4 \\
114.9\end{array}$ & $\begin{array}{l}5.29 \\
5.73\end{array}$ & $\begin{array}{l}9.98 \\
6.98\end{array}$ & -3.0 & -30 & $\begin{array}{l}\mathbf{x} \\
\mathbf{x}\end{array}$ \\
\hline \multirow[t]{2}{*}{ M. H. } & $\begin{array}{l}7.8 \\
7.6\end{array}$ & $\begin{array}{l}136 \\
130\end{array}$ & $\begin{array}{l}95 \\
89\end{array}$ & $\begin{array}{l}5.3 \\
5.5\end{array}$ & $\begin{array}{l}30 \\
32\end{array}$ & $\begin{array}{l}141.1 \\
134.7\end{array}$ & $\begin{array}{r}106.6 \\
99.6\end{array}$ & $\begin{array}{l}5.71 \\
5.92\end{array}$ & $\begin{array}{l}9.2 \\
6.9\end{array}$ & -2.3 & -25 & $\begin{array}{l}64 \pm \quad 5.4 \\
48 \pm\end{array}$ \\
\hline & & & & & & & & & & $\begin{array}{c}\text { Mean } \\
\text { S.E.M. } \\
\mathbf{t} \\
\mathbf{P}\end{array}$ & $\begin{array}{c}-26.1 \\
3.25 \\
8.0 \\
<.001\end{array}$ & \\
\hline
\end{tabular}

TABLE II

Effect of acute adrenal insufficiency-serum values and inulin space measurements before and two days after hormone withdrawal in adrenal-deficient patients

* Experimental values appear below their controls.

† Serum urea calculated from blood urea, hemoglobin, and serum protein in H. L., B. G. and M. R.; measured in the other patients.

$\ddagger$ Clearance not obtained. Estimated dead space correction based on urine flow.

$\$$ Clearance not obtained. Estimated dead space correction equivalent to 0.5 liter inulin space deducted from both determinations. 


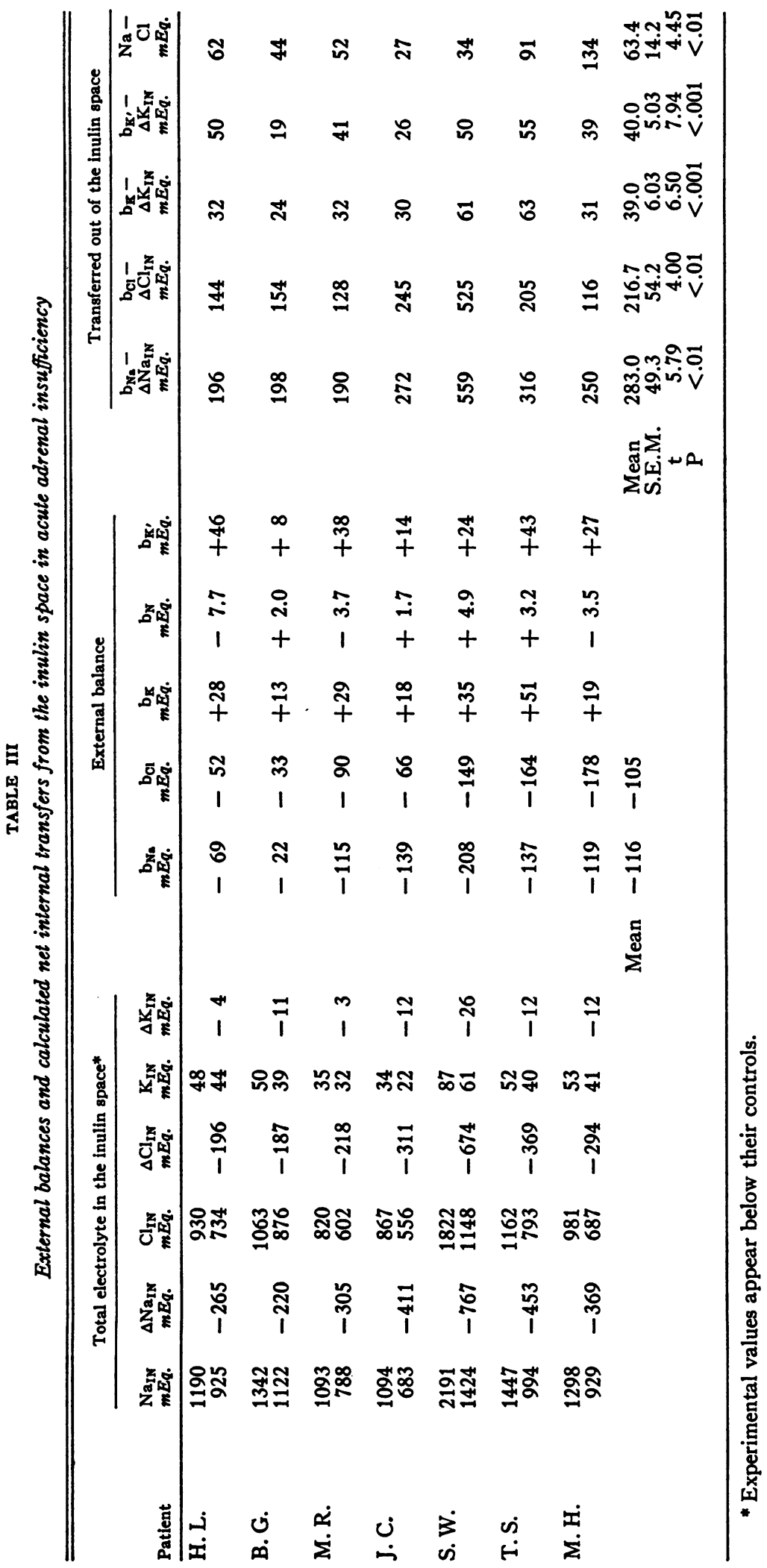


TABLE IV

Calculated change of chloride space and calculated net internal transfers of electrolytes from the chloride space in acute adrenal insufficiency

\begin{tabular}{|c|c|c|c|c|c|c|}
\hline \multirow[b]{2}{*}{ Patient } & & \multicolumn{3}{|c|}{ Change } & \multicolumn{2}{|c|}{$\begin{array}{l}\text { Transferred out of } \\
\text { chloride space }\end{array}$} \\
\hline & & $\begin{array}{l}\Delta \mathrm{E}_{\mathrm{cc}}^{*} \\
\text { liters }\end{array}$ & $\underset{m E q .}{\Delta \mathrm{Na}_{\mathrm{ac}} t}$ & $\begin{array}{l}\Delta \mathrm{K}_{\mathrm{Cl}} \ddagger \\
m E q .\end{array}$ & $\begin{array}{c}\mathrm{b}_{\mathrm{Na}}-\Delta \mathrm{Na}_{\mathrm{Cl}}{ }_{m \boldsymbol{q}} \\
.\end{array}$ & $\begin{array}{c}\mathrm{b}_{\mathbf{K}}-\Delta \mathrm{K}_{\mathrm{Cl}} \\
m E q .\end{array}$ \\
\hline \multirow[t]{2}{*}{$\begin{array}{l}\text { H. L. } \\
\text { B. G. } \\
\text { M. R. } \\
\text { J. C. } \\
\text { S. W. } \\
\text { T. S. } \\
\text { M. H. }\end{array}$} & & $\begin{array}{l}+0.2 \\
-0.3 \\
-0.9 \\
-0.7 \\
-0.8 \\
-1.2 \\
-1.1\end{array}$ & $\begin{array}{l}-90 \\
-21 \\
-147 \\
-126 \\
-141 \\
-193 \\
-207\end{array}$ & $\begin{array}{r}+4 \\
-4 \\
+3 \\
-3 \\
0 \\
-2 \\
-5\end{array}$ & $\begin{array}{r}21 \\
-\quad 1 \\
32 \\
-13 \\
-67 \\
56 \\
88\end{array}$ & $\begin{array}{l}42 \\
12 \\
35 \\
17 \\
24 \\
45 \\
32\end{array}$ \\
\hline & $\begin{array}{c}\text { Mean } \\
\text { S.E.M. } \\
\text { t } \\
\text { P }\end{array}$ & $\begin{array}{c}-.69 \\
.184 \\
3.75 \\
<.01\end{array}$ & & & $\begin{array}{c}17 \\
\text { Non-signi }\end{array}$ & $\begin{array}{c}29.6 \\
4.69 \\
6.31 \\
<.001\end{array}$ \\
\hline
\end{tabular}

* Calculated change of chloride space.

$\dagger$ Total sodium in the chloride space.

$\mp$ Total potassium in the chloride space.

$\$$ Minus values indicate transfers into chloride space.

on the assumption that the serum water represented 25 per cent of the total extracellular water. Electrolyte in the inulin space (Table III) is the product of the inulin space in liters times the concentration of electrolyte in extracellular water in milliequivalents per liter. The change in chloride space $\left(\Delta E_{\mathrm{cl}}\right)$ was calculated from the chloride balance and extracellular chloride concentration (17) on the assumption of an initial chloride space equal to the initial measured inulin space:

where

$$
\begin{aligned}
E_{\mathrm{Cl}_{2}} & =\frac{E_{\mathrm{IN}_{1}}(\mathrm{Cl})_{\mathrm{Cow}_{1}}+\mathrm{b}_{\mathrm{Cl}}}{(\mathrm{Cl})_{\mathrm{OOWl}_{2}}} \\
\Delta \mathrm{E}_{\mathrm{Cl}} & =\mathrm{E}_{\mathrm{Cl}_{2}}-\mathrm{E}_{\mathrm{IN}_{1}}
\end{aligned}
$$

$\mathrm{E}_{\mathrm{Cl}_{2}}=$ final chloride space in liters

$\mathrm{E}_{\mathrm{IN}_{1}}=$ initial inulin space in liters

$(\mathrm{Cl})_{\text {oow }_{1}}=$ initial extracellular water chloride concentration in milliequivalents per liter

$(\mathrm{Cl})_{\mathrm{eOW}_{2}}=$ final chloride concentration in extracellular water in milliequivalents per liter

$\mathrm{b}_{\mathrm{Cl}}=$ external balance of chloride in milliequivalents

The water balance was calculated, with one exception, according to the formula of Lavietes (18) :

$$
\Delta \mathrm{W}=\mathrm{W}_{\mathrm{t}}+\left(\mathrm{S}_{\mathrm{b}}-\mathrm{S}_{\mathrm{i}}\right)+\mathrm{C}_{\mathrm{i}}+\mathrm{F}_{\mathrm{b}}+3.38 \mathrm{~N}_{\mathrm{u}}
$$

where $S_{0}$ is solids of the excreta, $S_{1}$ solids of the ingesta, $C_{1}$ carbohydrate ingested, $F_{b}$ fat burned, and $N_{a}$ urine nitrogen, all in grams.

Solids of the stool, fluid intake, and solid food were measured by desiccation to constant weight in an oven at $100^{\circ} \mathrm{C}$. Urine solids were calculated by Long's coefficient (19) :

Urine solids $(\mathrm{Gm})=.2.66 \times$ last two figures of urinometer reading $\times$ urine volume in liters.
The fat burned was calculated according to the formula of Lavietes (18):

$$
F=\frac{I L-2.12 C_{i}-10.6 N_{u}}{3.78}
$$

where IL is the insensible loss of weight.

"Electrolyte unaccounted for" represents the algebraic difference between the change in the product of inulin space times extracellular water concentration of the respective electrolytes, and the net loss or gain of the corresponding electrolyte, measured as the external balance. The balances were calculated from 7 A.M. to 7 A.M. of the days on which the inulin space was measured, and the extracellular water concentration was calculated from 7 A.M. plasma values on those days. $K^{\prime}$ represents potassium moving independently of the catabolism or anabolism of tissues, and is derived from the potassium and nitrogen balances :

where

$$
b_{K^{\prime}}=b_{K}-\left(2.4 b_{N}\right)
$$

and $\begin{aligned} b_{K} & =\text { potassium balance in milliequivalents } \\ b_{N} & =\text { nitrogen balance in grams (17) }\end{aligned}$

The statistical methods employed are described by Snedecor (20).

\section{Chemical methods.5}

Inulin determinations were made by the method of Harrison (21). Sodium and potassium were determined on a flame photometer with internal lithium standard (22). The following methods were used for the other chemical analyses: chloride, Eisenman's modification (23) of the Van Slyke method; creatinine, Bonsnes and Taussky (24); urea, Karr (25); urine nitrogen and (in some instances)

5 We wish to thank Dr. John G. Reinhold and Dr. J. Kapp Clark for the performance of some of these analyses in their laboratories. 
TABLE V

Net internal transfers of water out of inulin space and chloride space in acute adrenal insufficiency

\begin{tabular}{|c|c|c|c|c|c|}
\hline Patient & $\begin{array}{c}\text { Body weight } \\
\text { (control) } \\
\text { K }_{\mathbf{B}} \text {. }\end{array}$ & ${ }_{K_{\boldsymbol{g}} .}^{\Delta W_{t}}$ & $\begin{array}{l}\Delta \mathrm{W}^{*} \\
\text { liters }\end{array}$ & $\Delta \mathrm{W}_{\text {liters }}-\Delta \mathrm{E}_{\mathrm{IN}} \dagger$ & $\Delta \mathrm{W}_{\text {liters }}-\Delta \mathrm{E}_{\mathrm{cl}} \ddagger$ \\
\hline $\begin{array}{l}\text { H. L. } \\
\text { B. G. } \\
\text { M. R. } \\
\text { J. C. } \\
\text { S. W. } \\
\text { T.S. } \\
\text { M. H. }\end{array}$ & $\begin{array}{l}64.88 \\
57.03 \\
71.46 \\
53.03 \\
88.24 \\
84.48 \\
43.93\end{array}$ & $\begin{array}{l}+.60 \\
+.07 \\
-.40 \\
-1.28 \\
=.36 \\
-.96 \\
-.80\end{array}$ & $\begin{array}{l}+.48 \\
+.16 \\
-.408 \\
-.90 \\
0 \\
-.57 \\
-.46\end{array}$ & $\begin{array}{l}1.7 \\
1.7 \\
1.6 \\
1.8 \\
5.3 \\
2.4 \\
1.8\end{array}$ & $\begin{array}{c}.28 \\
.46 \\
.50 \\
-.20 \| \\
.80 \\
.63 \\
.64\end{array}$ \\
\hline $\begin{array}{c}\text { Mean } \\
\text { S.E.M. } \\
\quad \text { t } \\
\quad \text { P }\end{array}$ & & $\begin{array}{c}-.45 \\
\text { Non- } \\
\text { significant }\end{array}$ & $\begin{array}{c}-.24 \\
\text { Non- } \\
\text { significant }\end{array}$ & $\begin{array}{l}2.33 \\
.505 \\
4.6 \\
<.01\end{array}$ & $\begin{array}{c}.447 \\
.124 \\
3.58 \\
<.02\end{array}$ \\
\hline
\end{tabular}

$* \Delta \mathrm{W}=$ Calculated change of total body water.

$\dagger \Delta W-\Delta E_{I N}=$ Net transfer of water out of the inulin space.

$\ddagger \Delta W-\Delta E_{C l}=$ Net transfer of water out of the chloride space.

$\Delta \mathrm{W}=\Delta \mathrm{Wt}$. (Stool solids not measured.)

Minus values indicate net transfer into the chloride space.

serum protein by a micro-Kjeldahl method using a selenium catalyst and boric acid titration; serum protein in other instances by the method of Wolfson, Cohn, Calvary, and Ichiba (26).

\section{RESULTS}

Direct observations, derived data, and interpretive calculations are presented in Tables II to VIII inclusive.

\section{A. Effects of acute adrenal insufficiency}

A large decrease in the volume of distribution of inulin was uniformly observed, amounting to $26.1 \pm 3.25$ per cent (Table II). ${ }^{6}$ Net external

B If, during the precipitation of acute adrenal insuffciency, there occurred a reduction of inulin clearance to such an extent that the recovery of inulin in the 18-hour urine collection was notably less during this second measurement of the inulin space as compared with the control, a factitial decrease of the inulin space would result. To evaluate this possible source of error, inulin recovery was separately determined in two of the subjects in whom inulin clearance was in the range of the lowest values observed in the group. In these two patients (T. S. and J. C.) recoveries of 94 per cent and 93 per cent were obtained at 18 hours with inulin clearances of $47 \pm 1$ and $67 \pm 1 \mathrm{ml}$. per min., respectively. Even a decrease from normal to half the normal filtration rate or less between measurements would therefore occasion an error of only about 7 per cent. However, the control values themselves (Table II) were already markedly subnormalsomewhat, though not strikingly, lower than is expected in Addison's disease $(27,28)$; and since the decreases of filtration rate in adrenal insufficiency were never large (Table II), it is difficult to suppose that a factitial decrease of the inulin space could have amounted to more than 1 or 2 per cent in these experiments. water loss, when it occurred, was never large enough to account for the decrease of the inulin space (Table V). Ignoring certain reservations to be discussed one may regard the change of the inulin space corrected for external water balance $\left(\Delta \mathrm{W}-\Delta \mathrm{E}_{\mathrm{IN}}\right.$, Table $\left.\mathrm{V}\right)$ as a measure of water transferred in adrenal insufficiency, i.e., disappearing from the inulin space into some other compartment of body water.

Concentrations of electrolytes and urea nitrogen in serum and extracellular water on the day of the inulin space determinations are given in Table II, and in Table III are shown calculated total sodium, chloride, and potassium in the inulin space at the time of each measurement $\left(\mathrm{Na}_{\mathrm{IN}}, \mathrm{Cl}_{\mathrm{IN}}, \mathrm{K}_{\mathrm{IN}}\right.$, Table III). Calculated net change in these quantities in association with acute adrenal insufficiency is also shown in Table III, and this change is compared with net external losses of sodium and chloride and the net external gain of potassium over the same period $\left(b_{\mathrm{Na}}, b_{\mathrm{Cl}}, b_{\mathbf{K}}, b_{\mathbf{K}^{\prime}}\right)$. Electrolyte "transferred" again represents the calculated change of electrolyte in the inulin space corrected for external balance.

A lesser but still significant calculated decrease of the chloride space was observed $\left(\Delta \mathrm{E}_{\mathrm{ol}}\right.$, Table IV). Calculated change of total sodium and potassium in the chloride space is also shown $\left(\Delta \mathrm{Na}_{\mathrm{Cl}}\right.$, $\Delta \mathrm{K}_{\mathrm{Cl}}$, Table IV). Significant "transfers" from the chloride space, calculated exactly as in the case of the inulin space, are indicated for water $\left(\Delta \mathrm{W}-\Delta \mathrm{E}_{\mathrm{Cl}}\right.$, Table $\left.\mathrm{V}\right)$ and for potassium $\left(\mathrm{b}_{\mathbf{K}^{\prime}}-\right.$ 
$\Delta \mathrm{K}_{\mathrm{Ol}}$, Table IV), but not for sodium $\left(\mathrm{b}_{\mathrm{Na}}-\right.$ $\Delta \mathrm{Na}_{\mathrm{ol}}, \mathrm{Table}$ IV).

\section{B. Control observations}

In Table VI are presented data indicating that reduction of dietary salt in the manner employed in the standard regimen, with or without withdrawal of cortisone, is not followed by decrease of the inulin space when adrenal insufficiency does not ensue owing to the availability of adrenocortical reserve; and further that extreme reduction of dietary sodium did not in three days result in diminution of the inulin space in an individual possessing adequate adrenocortical function.

\section{Effects of steroids}

The data in Table VII indicate that cortisone, hydrocortisone, and desoxycorticosterone are all capable of effecting changes in fluid distribution in a fashion contrary to the effects of acute adrenal insufficiency. Thus, the substitution of cortisone (75 mg. daily) for desoxycorticosterone $(6 \mathrm{mg}$. daily) produced in T. S. a small increase in the inulin space; the addition of desoxycorticosterone to cortisone a larger increase in J. V.; whereas a very large increase of the inulin space was observed when hydrocortisone was administered to M. $H$. at a time when the patient was in a state of acute adrenal insufficiency. Smaller increases in the chloride space were observed in these three patients. In two out of three patients (B. G.,
M. R., and J. C.) who were in a state of acute adrenal insufficiency increases of the inulin space were observed in less than one hour following administration of cortisone intravenously.

\section{DISCUSSION}

The observations reported in this communication show that external water loss is neither a conspicuous nor a constant feature of acute adrenal insufficiency in man. Internal transfers of water are, however, regularly indicated; and external loss of sodium and chloride appears to be overshadowed by the internal transfers of these ions which accompany the condition. The measurements also disclose that such internal transfers regularly precede the development of hyponatremia, for in five patients no abnormal decrease of serum sodium concentration had supervened at the time of the second (experimental) measurements. Therefore, while it is presumably true that hyponatremia of the extracellular fluid, when it occurs, will occasion osmotic transfer of water into cells, hyponatremia clearly was not the important initiator of the transfers observed in these patients.

On the other hand hyponatremia cannot be regarded as a simple consequence of the fluid transfers, since, on any interpretation of the data, more water than sodium is transferred out of the extracellular compartment. Net external loss of sodium is, however, relatively much greater than net external water loss ( $b_{\mathrm{Na}}$, Table III ; $\Delta \mathrm{W}$, Table V).

TABLE VI

Salt and hormone withdrawal without resulting adrenal insufficiency-inulin space measurements

\begin{tabular}{|c|c|c|c|c|c|c|c|c|}
\hline \multirow[b]{3}{*}{ Patient } & \multirow[b]{3}{*}{ Diagnosis } & \multirow{2}{*}{\multicolumn{2}{|c|}{$\frac{\text { Control }}{\text { Daily ration }}$}} & \multicolumn{3}{|c|}{ Experimental } & \multirow{2}{*}{\multicolumn{2}{|c|}{ Inulin space }} \\
\hline & & & & \multicolumn{2}{|c|}{ Daily ration } & \multirow[b]{2}{*}{$\begin{array}{c}\text { Duration } \\
\text { days }\end{array}$} & & \\
\hline & & $\begin{array}{l}\text { Corti- } \\
\text { sone } \\
\text { mg. }\end{array}$ & $\begin{array}{l}\text { Dietary } \\
\text { sodium } \\
\text { mEq. }\end{array}$ & $\begin{array}{l}\text { Corti- } \\
\text { oone } \\
\text { mg. }\end{array}$ & $\begin{array}{c}\text { Dietary } \\
\text { sodium } \\
m E q .\end{array}$ & & $\underset{\substack{\mathrm{E}_{\mathrm{IX}} \\
\text { liters }}}{\text {. }}$ & $\begin{array}{c}\Delta \mathrm{E}_{\mathrm{IN}} \\
\text { liters }\end{array}$ \\
\hline M.M. & $\begin{array}{l}\text { Hypertension; } \\
\text { prior subtotal } \\
\text { adrenalectomy; } \\
\text { positive ACTH } \\
\text { response }\end{array}$ & 4 & 175 & 0 & 108 & 2 & $\begin{array}{l}8.6 \\
9.1\end{array}$ & +0.5 \\
\hline E. M. & $\begin{array}{l}\text { Hypertension; } \\
\text { prior subtotal } \\
\text { adrenalectomy; } \\
\text { positive ACTH } \\
\text { response }\end{array}$ & 0 & 248 & 0 & 111 & 2 & $\begin{array}{l}10.4 \\
10.3\end{array}$ & -0.1 \\
\hline F. N. & $\begin{array}{l}\text { Hypertension; } \\
\text { no surgical } \\
\text { treatment }\end{array}$ & 0 & 146 & 0 & 12 & 3 & $\begin{array}{l}10.0 \\
11.5\end{array}$ & +1.5 \\
\hline
\end{tabular}

* Experimental values appear below their controls. 


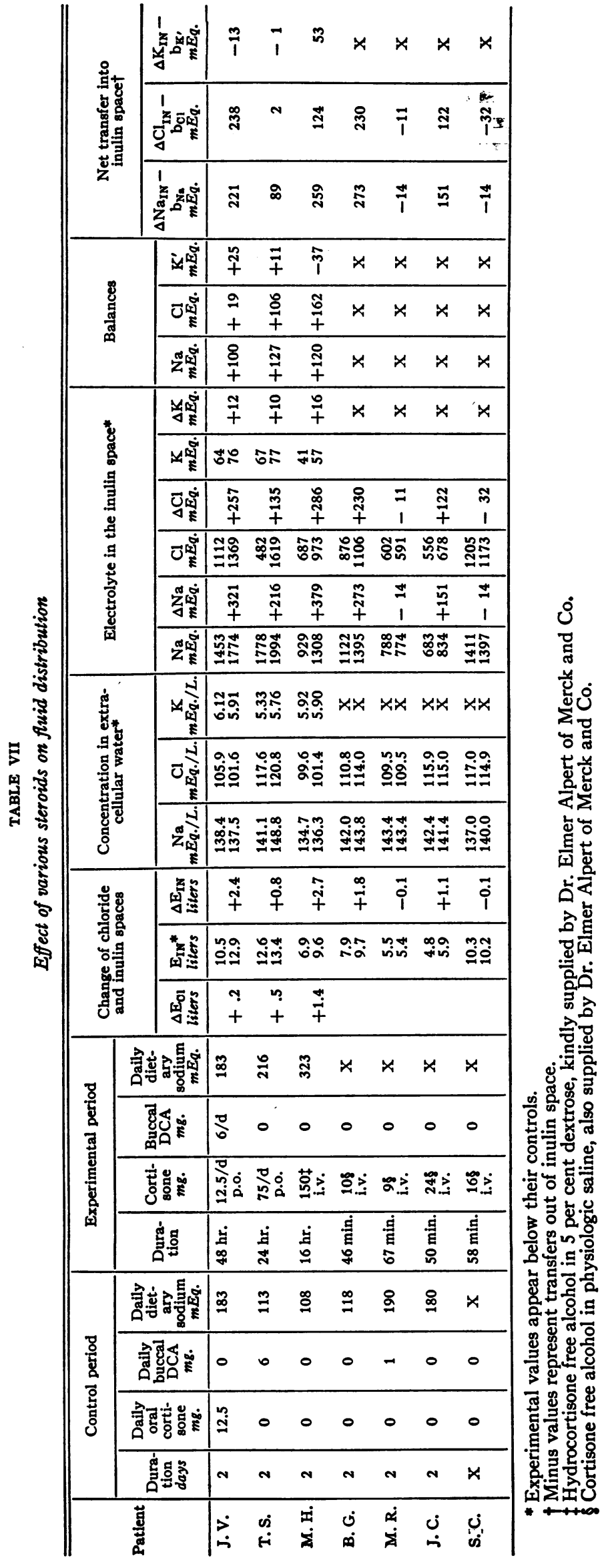


TABLE VIII

Calculated transfers of water and electrolyte out of the inulin space but not out of the chloride space in acute adrenal insufficiency

\begin{tabular}{ccccc}
\hline \hline & $\begin{array}{c}\Delta \mathrm{E}_{\mathrm{Cl}}-\Delta \mathrm{E}_{\mathrm{IN}} \\
\text { liters }\end{array}$ & $\begin{array}{c}\Delta \mathrm{Na}_{\mathrm{Cl} 1}-\Delta \mathrm{Na}_{\mathrm{IN}} \\
m E q .\end{array}$ & $\begin{array}{c}\mathrm{b}_{\mathrm{Cl}}-\Delta \mathrm{Cl}_{\mathrm{IN}} \\
m E q .\end{array}$ & $\begin{array}{c}\Delta \mathrm{K}_{\mathrm{Cl}}-\Delta \mathrm{K}_{\mathrm{IN}} \\
m E q .\end{array}$ \\
\hline Patient & 1.4 & 175 & 144 & 8 \\
H. L. & 1.2 & 199 & 154 & 7 \\
B. G. & 1.1 & 158 & 128 & 6 \\
M. R. & 2.0 & 285 & 245 & 9 \\
J. C. & 4.5 & 626 & 525 & 26 \\
S. W. & 4.5 & 260 & 205 & 10 \\
T.S. & 1.8 & 162 & 116 & 7 \\
M. H. & 1.2 & & & \\
& & & & \\
Mean & 1.89 & 266.4 & 216.7 & 10.4 \\
S.E.M. & .45 & 62.7 & 54.2 & 2.6 \\
t & 4.20 & 4.25 & 4.00 & 4.00 \\
P & $<.01$ & $<.01$ & $<.01$ & $<.01$ \\
\hline
\end{tabular}

It would, therefore, appear that hyponatremia, when it occurs in acute adrenal insufficiency, is ascribable primarily to renal wastage of sodium. The effectiveness of net external loss of sodium in reducing the concentration of sodium in extracellular fluid would, however, be enhanced by any concurrent depletion of the volume and total sodium content of extracellular fluid brought about by internal transfers of fluid.

The plan of the experiments in which steroid was withdrawn from adrenal-deficient patients was designed to disclose information concerning acute adrenal insufficiency. ${ }^{7}$ Our reported observations may well not be applicable to subacute or chronic adrenal insufficiency resulting from a more prolonged and less severe lack of hormone in relation to requirement; and indeed weight loss is generally regarded as a cardinal and even indispensible feature of the latter conditions.

Withdrawal of replacement steroid from the adrenal-deficient subject is a valid method for the experimental study of adrenal insufficiency, and indeed the only feasible way to study uncomplicated acute adrenal insufficiency. Since the patients were receiving during the control period approximately the minimum exogenous hormone capable of maintaining their well-being, it is proper to emphasize that the fluid transfers observed are

\footnotetext{
7 There is need in endocrinology for two terms which will be generally acceptable as expressing two distinct concepts: 1) lack of functioning endocrine tissue, and 2) physiologic consequences resulting from such lack. In this communication, for want of better terminology, we understand by adrenal insufficiency, manifestations attributable to lack of adrenal hormone in relation to need, and by adrenal deficiency, simple deficit of adrenal tissue.
}

not to be regarded as effects of withdrawal of steroids exhibited in pharmacologic quantity. The transfers were observed whether or not dietary salt was reduced when hormone was withdrawn (Table I). Similar transfers did not accompany drastic dietary salt reduction in the hypertensive subject with intact adrenal glands; nor have they occurred, under the standard conditions employed in the present series, in subtotally adrenalectomized subjects manifesting evidence of adrenocortical reserve (Table VI). They are therefore, so far as can be determined by the available data, a specific effect of acute adrenal insufficiency. They are moreover preventable or reversible indiscriminately by desoxycorticosterone, hydrocortisone, or cortisone; and the latter compound, at least, can apparently moderate or even rectify the abnormal fluid distribution of acute adrenal insufficiency within as short a time as an hour (Table VII).

There is little reason to suppose that the coexistence of vascular disease modified the effects of induced acute adrenal insufficiency upon fluid distribution in these patients, though of course this possibility may be kept in mind. Certainly the changes observed are quite similar to those reported in normal dogs $(5,6)$. Gaudino and Levitt (5) indeed reported much larger percentile decreases of the inulin space in dogs developing acute adrenal insufficiency; the difference may well be ascribable to a difference in the severity of acute adrenal insufficiency which was permitted to develop in canine and human subjects, respectively.

More precise characterization of the fluid and electrolyte transfers which occurred in these patients depends upon the anatomical boundaries which are to be assigned to the volumes of distribution of inulin and of chloride. Although the volumes of distribution of these substances have both been extensively used as approximations of extracellular fluid volume, objections have been urged against the use of each method for this purpose, and definition of the anatomical boundaries corresponding to these volumes is a matter of controversy.

Chloride is admittedly present in the cells of certain tissues $(29,30)$; the justification for the use of its volume of distribution as a measure of extracellular fluid volume must therefore rest upon the premise that intracellular chloride is either so small in quantity as compared with extracellular 
chloride, or that the quantity of exchangeable intracellular chloride changes so little under the conditions of any particular study, or both, that the error in estimating extracellular fluid changes as the change of the chloride space is small. Hastings (30) reviewed the extensive though necessarily indirect evidence which led to rather general acceptance of such assumptions. Conclusive direct evidence as to the quantity, and of the stability of cell chloride under pathological circumstances, is nevertheless lacking. It has been maintained (31) that a very large proportion of total body chloride-as much as a third-is intracellular; but the chief support for this contention is derived from unqualified acceptance of the identity of extracellular fluid volume and the volume of distribution of inulin-an assumption which is itself open to question.

When inulin is administered to man by the technique employed in these experiments, equilibrium distribution in a virtually constant limiting fluid volume is said to be attained (in the absence of abnormal fluid collections) at the end of a fivehour infusion. This finding, together with evidence that inulin does not pass cell membranes, affords the chief basis for the view of some investigators $(15,32,33,34)$ that the inulin space corresponds to extracellular fluid volume. It is not clear, however, that any satisfactory evidence has been cited to exclude the possibility that the volume of distribution of inulin may correspond to a subcompartment of the extracellular fluid. Nichols, Nichols, Weil, and Wallace (35) concluded, on the basis of analytical studies of particular tissues following inulin administration to dogs, that the inulin space is a less satisfactory measure of extracellular fluid volume than the chloride space, owing to deficient penetration of inulin into connective tissue. One may accordingly entertain the alternative view that the chloride space comprises the entire inulin space and in addition includes a connective tissue compartment exhibiting essentially the chemical characteristics of extracellular fluid modified by the presence of connective tissue proteins.

If the inulin space is accepted as a valid measurement of extracellular fluid volume, ${ }^{8}$ the data

$8 \mathrm{On}$ this assumption, it is not possible for any effects of a disease state on cell permeability to produce a factitial decrease of the inulin space, since, according to hypo- would indicate intracellular migration of large quantities of water, sodium, chloride, and potassium in acute adrenal insufficiency, the quantities transferred into cells being given by deducting from the total decrease of the inulin space and its contained ions the net external loss of these substances $\left(\Delta \mathrm{W}-\Delta \mathrm{E}_{\mathrm{IN}}\right.$, Table $\mathrm{V} ; \mathrm{b}_{\mathrm{Na}}-\Delta \mathrm{Na}_{\mathrm{IN}}$ and $\mathrm{b}_{\mathrm{Cl}}-\Delta \mathrm{Cl}_{\mathrm{IN}}$, Table III) or adding the net external gain ( $b_{K^{\prime}}-\Delta K_{I N}$, Table III). A significant excess of sodium over chloride is transferred (transferred $\mathrm{Na}-\mathrm{Cl}$, Table III). These ions move in approximately the proportion of their relative concentrations in extracellular fluid; while potassium and water, according to their proportions in extracellular fluid relative to sodium or chloride, are transferred in excess. Transfers in the opposite sense would be effected by adrenal steroids (Table VII).

If, on the other hand, the chloride space affords a valid approximation to extracellular fluid volume, and if it exceeds the inulin space by virtue of including a large volume of connective tissue water, the interpretation of the data is somewhat more complex. The decrease of the chloride space, and of the calculated sodium and potassium of the chloride space, after correction for external balance, will represent transfers into the cellular compartment $(\Delta \mathrm{W}$ $-\Delta \mathrm{E}_{\mathrm{Cl}}$, Table $\mathrm{V} ; \mathrm{b}_{\mathrm{Na}}-\Delta \mathrm{Na}_{\mathrm{Cl}}, \mathrm{b}_{\mathrm{K}^{\prime}}-\Delta \mathrm{K}_{\mathrm{Ol}}$, Table IV). The decrease of the inulin space in excess of the decrease of the chloride space will represent transfer of fluid out of the inulin space, but not out of the chloride space $\left(\Delta \mathrm{E}_{\mathrm{Cl}}-\Delta \mathrm{E}_{\mathrm{IN}} \text {, Table VIII }\right)^{\circ}$;

thesis, there is normally no penetration beyond the extracellular phase throughout which inulin is homogeneously diffused. Any abnormal penetration of inulin into cells would cause a factitial increase of the apparent inulin space.

9 An alternate interpretation of the discrepancy between the magnitudes of change of the inulin space and the chloride space would ascribe to adrenal hormones an effect upon the penetrability to inulin of the connective tissue. On this view, it would be supposed that in adrenal insufficiency inulin gains access to connective tissue water to a much lesser extent than in the normal individual, so that the apparent decrease of the inulin space would be artifactual. There is no way to exclude this possibility; but it must be said that one is still confronted with the necessity of attributing to adrenal hormones profound effects upon the physicochemical state of collagen, and that the internal transfers of fluid as calculated on the basis of the chloride space are not brought into question by this hypothesis. 
and the calculated electrolyte losses from the inulin space in excess of electrolyte losses from the chloride space will similarly represent transfer of these ions out of the inulin space, but not out of the chloride space $\left(\Delta \mathrm{Na}_{\mathrm{Ol}}-\mathrm{Na}_{\mathrm{IN}}, \mathrm{b}_{\mathrm{Ol}}-\Delta \mathrm{Cl}_{\mathrm{IN}}\right.$, $\Delta \mathrm{K}_{\mathrm{Cl}}-\Delta \mathrm{K}_{\mathrm{IN}}$, Table VIII). According to the hypothesis, the figures will express the magnitudes of transfer of water and electrolytes from the inulin space into connective tissue.

If this interpretation of the data is adopted, the figures imply that in every instance the bulk of the fluid transfer in acute adrenal insufficiency is attributable to increased hydration of the connective tissue brought about by movement of water, sodium, chloride, and potassium in quantities closely corresponding to their relative proportions in extracellular fluid. Movement into the cellular compartment of water and of large amounts of potassium, without transfer of sodium, would also be implied.

This second interpretation of the data agrees with reports based on tissue analysis, in that the sodium apparently transferred from extracellular fluid in adrenal insufficiency could never be found in the cells of any of the soft tissues examined (skeletal muscle, heart muscle, liver and kidney), and would suggest the connective tissue as the site of the missing sodium. The agreement was perhaps to be expected, inasmuch as the chloride space was used as the measure of extracellular fluid volume when calculations of cell composition were applied to the reported tissue studies. Direct chemical analysis of the connective tissue of animals dying in acute adrenal insufficiency would be of great interest. If a greatly increased content of water and sodium of this tissue were found to accompany adrenal insufficiency, support would be provided for the utility of simultaneous estimates of the changes in inulin and chloride space in studying fluid distribution in the intact organism, and for the view of Nichols et al. that the inulin space does not include some of the plasma-ultrafiltrate phase of connective tissue water. Ludwig, Chen, and Soffer (36) have observed that the hydration of connective tissue is affected by certain steroid hormones; and adrenal cortical regulation of the hydration of connective tissue would be a matter of considerable interest in view of the spectacular effects of cortisone upon diseases affecting collagenous tissue.

\section{SUMMARY}

1. Acute adrenal insufficiency induced in seven adrenal-deficient patients was attended by a significant decrease of the chloride space (calculated) and a much larger decrease of the inulin space (measured).

2. The calculated net loss of potassium and water from the chloride space, and of sodium, chloride, potassium, and water from the inulin space, could not be attributed to net external loss. Internal transfers of fluid and electrolytes, therefore, accompany acute adrenal insufficiency in man.

3. Interpretation of the nature of the observed transfers depends upon the anatomical boundaries to be assigned the volumes of distribution of chloride and of inulin. Alternative interpretations of the data are presented.

4. Desoxycorticosterone, hydrocortisone, and cortisone are all individually capable of preventing or correcting the abnormal distribution of body fluid characteristic of acute adrenal insufficiency; in the case of intravenous cortisone, corrective effects may be observed within an hour.

\section{ACKNOWLEDGMENTS}

We wish to express our thanks to Drs. J. Russell Elkinton and William A. Jeffers for their helpful advice and support.

We are indebted, also, to Miss Helen Merton, Mrs. Cynthia Henderson, and the nursing staff of the Metabolic Unit, and to Miss Marie Wackermann, who was wholly responsible for the dietary management. Miss Catherine Macatsoris, Mr. William Luetzell, Mrs. Kathryn Boyer, and Miss Virginia Alexa contributed technical assistance.

Dr. William Fitts performed the adrenalectomy in S. W.; all the other adrenal resections were done by $\mathrm{Dr}$. Harold A. Zintel.

Maintenance of hormone therapy for our postadrenalectomy patients has been supplied gratis through the kindness of Drs. Elmer Alpert and Augustus Gibson of Merck and Company (cortone 8 ) ; Dr. F. L. Mohr, of Ciba Pharmaceutical Products, Inc. (percorten(8); and Dr. R. W. Burlew, of Schering Corporation (cortate $\otimes$ ).

\section{REFERENCES}

1. Swingle, W. W., Pfiffner, J. J., Vars, H. M., and Parkins, W. M., The effect of fluid deprivation and fluid intake upon the revival of dogs from adrenal insufficiency. Am. J. Physiol., 1934, 108, 144.

2. Swingle, W. W., Parkins, W. M., Taylor, A. R., and Hays, H. W., Relation of serum sodium and chloride levels to alterations of body water in the intact and adrenalectomized dog, and the influence 
of adrenal cortical hormone upon fluid distribution. Am. J. Physiol., 1936, 116, 438.

3. Swingle, W. W., Parkins, W. M., Taylor, A. R., and Hays, H. W., A study of water intoxication in the intact and adrenalectomized dog and the influence of adrenal cortical hormone upon fluid and electrolyte distribution. Am. J. Physiol., 1937, 119, 557.

4. Swingle, W. W., Parkins, W. M., Taylor, A. R., and Hays, H. W., The influence of adrenal cortical hormone upon electrolyte and fluid distribution in adrenalectomized dogs maintained on a sodium and chloride free diet. Am. J. Physiol., 1937, 119, 684.

5. Gaudino, M., and Levitt, M. F., Influence of the adrenal cortex on body water distribution and renal function. J. Clin. Invest., 1949, 28, 1487.

6. Flanagan, J. B., Davis, A. K., and Overman, R. R., Mechanism of extracellular sodium and chloride depletion in the adrenalectomized dog. Am. J. Physiol., 1950, 160, 89.

7. Harrison, H. E., and Darrow, D. C., The distribution of body water and electrolytes in adrenal insufficiency. J. Clin. Invest., 1938, 17, 77.

8. Darrow, D. C., Harrison, H. E., and Taffel, M., Tissue electrolytes in adrenal insufficiency. J. Biol. Chem., 1939, 130, 487.

9. Muntwyler, E., Mellors, R. C., Mautz, F. R., and Mangun, G. H., Electrolyte and water equilibria in the dog. II. Electrolyte and water exchange between skeletal muscle and blood in adrenal insufficiency. J. Biol. Chem., 1940, 134, 367.

10. Buell, M. V., and Turner, E., Cation distribution in the muscles of adrenalectomized rats. Am. J. Physiol., 1941, 134, 225.

11. Swingle, W. W., and Remington, J. W., The role of the adrenal cortex in physiological processes. Physiol. Rev., 1944, 24, 89.

12. Stern, T. N., Cole, V. V., Bass, A. C., and Overman, R. R., Dynamic aspects of sodium metabolism in experimental adrenal insufficiency using radioactive sodium. Am. J. Physiol., 1951, 164, 437.

13. Overman, R. R., Sodium, potassium and chloride alterations in disease. Physiol. Rev., 1951, 31, 285.

14. Hills, A. G., Webster, G. D., Rosenthal, O., Dohan, C. F., Richardson, E. M., Zintel, H. A., and Jeffers, W. A., Quantitative evaluation of primary adrenal cortical deficiency in man. Am. J. Med., (In press).

15. Schwartz, I. L., Schachter, D., and Freinkel, N., The measurement of extracellular fluid in man by means of a constant infusion technic. J. Clin. Invest., 1949, 28, 1117.

16. Eisenman, A. J., Mackenzie, L. B., and Peters, J. P., Protein and water of serum and cells of human blood, with a note on the measurement of red blood cell volume. J. Biol. Chem., 1936, 116, 33.

17. Elkinton, J. R., and Winkler, A. W., Transfers of intracellular potassium in experimental dehydration. J. Clin. Invest., 1944, 23, 93.

18. Lavietes, P. H., The metabolic measurement of the water exchange. J. Clin. Invest., 1935, 14, 57.
19. Long, J. H., On the relation of the specific gravity of urine to the solids present. J. Am. Chem. Soc., 1903. 25, 257.

20. Snedecor, G. W., Statistical Methods Applied to Experiments in Agriculture and Biology, ed. 4, Ames. Iowa State College Press, 1946.

21. Harrison, H. E., A modification of the diphenylamine method for determination of inulin. Proc. Soc. Exper. Biol. \& Med., 1942, 49, 111.

22. Wallace, W. M., Holliday, M., Cushman, M., and Elkinton, J. R., The application of the internal standard flame photometer to the analysis of biologic material. J. Lab. \& Clin. Med., 1951, 37, 621.

23. Eisenman, A. J., A note on the Van Slyke method for the determination of chlorides in blood and tissue. J. Biol. Chem., 1929, 82, 411.

24. Bonsnes, R. W., and Taussky, H. H., On the colorimetric determination of creatinine by the Jaffe reaction. J. Biol. Chem., 1945, 158, 581.

25. Karr, W. G., A method for the determination of blood urea nitrogen. J. Lab. \& Clin. Med., 1924, 9, 329.

26. Wolfson, W. Q., Cohn, C., Calvary, E., and Ichiba, F., Studies in serum proteins. A rapid procedure for the estimation of total protein, true albumin, total globulin, alpha globulin, beta globulin, and gamma globulin in $1.0 \mathrm{ml}$. of serum. Am. J. Clin. Path., 1948, 18, 723.

27. Talbott, J. H., Pecora, L. J., Melville, R. S., and Consolazio, W. V., Renal function in patients with Addison's disease and in patients with adrenal insufficiency secondary to pituitary pan-hypofunction. J. Clin. Invest., 1942, 21, 107.

28. Waterhouse, C., and Keutmann, E. H., Kidney function in adrenal insufficiency. J. Clin. Invest., 1948, 27, 372.

29. Manery, J. F., and Hastings, A. B., The distribution of electrolytes in mammalian tissues. J. Biol. Chem., 1939, 127, 657.

30. Hastings, A. B., The electrolytes of tissues and body fluids. Harvey Lect., 1940-41, 36, 91.

31. Steele, J. M., Body water. Am. J. Med., 1950, 9, 141.

32. Gaudino, M., Schwartz, I. L., and Levitt, M. F., Inulin volume of distribution as a measure of extracellular fluid in dog and man. Proc. Soc. Exper. Biol. \& Med., 1948, 68, 507.

33. Gaudino, M., and Levitt, M. F., Inulin space as a measure of extracellular fluid. Am. J. Physiol., 1949, 157, 387.

34. Levitt, M. F., and Gaudino, M., Measurement of body water compartments. Am. J. Med., 1950, 9, 208.

35. Nichols, G., Jr., Nichols, N., Weil, W. B., and Wallace, W. M., The direct measurement of the extracellular phase of tissues. J. Clin. Invest., 1952, 31, 652.

36. Ludwig, A. W., Chen, D. K., and Soffer, L. J., The relationship between connective tissue mucopolysaccharide content and tissue electrolyte composition. J. Clin. Endocrinol. \& Metab., 1952, 112, 965. 